Debreceni Jogi Műhely 2018. (XV.) 1-2.

Debreceni Egyetem, Állam- és Jogtudományi Kar, Debrecen

(University of Debrecen, Faculty of Law, Debrecen)

DOI 10.24169/DJM/2018/1-2/2

Gyüre Péter

birósági titkár

Kisvárdai Járásbiróság

\title{
A BÍRÓSÁGI VÉGREHAJTÁSI ELJÁRÁS CSELEKMÉNYEINEK LÁNCOLATÁT ÁTMENETILEG MEGAKASZTÓ JOGINTÉZMÉNYEK
}

Debreceni Jogi Múhely, 2018. évi (XV. évfolyam) 1-2. szám (2018. július 8.)

DOI 10.24169/DJM/2018/1-2/2

Legal institutions that interrupt temporarily the chain of procedural actions of the judicial foreclosure Summary

This study presents the legal institutions that temporarily interrupt the chain of procedural actions of the judicial foreclosure, namely the interruption, suspension and intermission of the foreclosure. In the publication - as an acting lawyer - pragmatism has an emphasised role and it highlights the problems that arise when applying the legal institutions and offers alternatives and de lege ferenda solutions. The author seeks to draw the reader's attention to the interrelations and differences between legal institutions for the sake of clarity. Furthermore the speciality of this study is that it uses the civil procedural regulations which are applicable as a background standard for the Code of Judicial Foreclosure, from the new Code of Civil Procedure which entered into force on 1 January 2018, referring in several places simultaneously to the regulations of the previous CCP.

\section{Bevezetés}

A bírósági végrehajtás olyan önálló, törvényileg szabályozott eljárás, amelyben állami vagy meghatározott szempontból azzal azonosnak minősülő szerv, elsősorban vagyoni kényszer alkalmazása révén juttatja érvényre az állam által a konkrét egyedi ügyben fennállónak elismert és kikényszeríthető alanyi jogot vagy előzetesen biztosítja a konkrét egyedi ügyben történő elismerés vagy kikényszeríthetőség előtt védelemben részesített alanyi jog későbbi érvényre juttatását. ${ }^{1}$ A meglehetősen precíz fogalom meghatározást azzal a nem mellékes elemmel egészíthetjük ki, hogy a definiált eljárás nemperes eljárás. ${ }^{2}$

A polgári peres és nemperes eljárások a felek és az eljáró szerv (bíróság, hatósági szervezet) eljárási cselekményeinek láncolata. A már folyó, megindított eljárás alatt felmerülhetnek olyan körülmények, bekövetkezhetnek olyan események, amikor az eljárási cselekmények folytathatatlanok, avagy folytatásuk egyszerűen céltalan. Lehetséges, hogy az eljárás megindításának feltételei az eljárás alatt megszűnnek (például meghal az adós), vagy az eljárás zavartalanságához szükséges körülmények többé nem biztosítottak (például a végrehajtási eljárásba bejelentkezik a zálogjogosult).

A végrehajtási mechanizmus megakadása történhet átmeneti jelleggel, de akár véglegesen is. Utóbbi eklatáns példája a megszüntetés, míg előbbiek tipikusan a félbeszakadás, felfüggesztés és szünetelés. Annak ellenére, hogy mindhárom az eljárás cselekményeinek láncolatát időlegesen megakasztó jogintézmény, eltérő rendszertani elhelyezkedéssel és sajátos specifikumokkal bírnak. Jelen tanulmány célja, hogy ezeket a teljességre való törekvés szándéka nélkül prezentálja.

\footnotetext{
${ }^{1}$ Kapa Mátyás: A közjegyző szerepe a bírósági végrehajtásban, Közjegyzők közlönye, 2010/4. szám, 21-38., 21.

${ }^{2}$ Udvary Sándor: A bírósági végrehajtási eljárás, In: Wopera Zsuzsa (szerk.): Polgári eljárásjog II., Budapest, HVG Orac, 2013. 218.
} 
Debreceni Jogi Múhely 2018. (XV.) 1-2.

Debreceni Egyetem, Állam- és Jogtudományi Kar, Debrecen

(University of Debrecen, Faculty of Law, Debrecen)

DOI 10.24169/DJM/2018/1-2/2

\section{A bírósági végrehajtás félbeszakadása}

A polgári eljárás nyugvásának egyik formája az eljárás félbeszakadása. Ha meghatározott esemény vagy állapot bekövetkezik, az eljárás félbeszakad. A félbeszakadást előidéző okok ugyanis gátolják az eljárás további folytatását, az ügy érdemi elbírálását. A félbeszakadásra vonatkozó részletszabályokat a 2018. január 1-jén hatályba lépett új polgári perrendtartásról szóló 2016. évi CXXX. törvény (a továbbiakban: Pp.) 119. és 120. \ tartalmazza, következtetésképpen jelen jogintézmény alkalmazhatóságát a bírósági végrehajtásról szóló 1994. évi LIII. törvény (a továbbiakban: Vht.) 9. \$-a teszi lehetôvvé. ${ }^{3}$ A Vht. 9. \-a egy utaló rendelkezést tartalmaz azokra az eljárási kérdésekre, amelyeket a törvény külön nem szabályoz. Ezen esetekben ugyanis a Pp. szabályai lesznek irányadóak, vagyis a Pp. mögöttes jelleggel, szubszidiárius jogforrásként jelenik meg a bírósági végrehajtás során. ${ }^{4} \mathrm{~A}$ jogalkotó a félbeszakadás törvényi eseteit taxatív módon határozza meg, melyek a perbeli jog-, illetve cselekvőképesség elvesztéshez, a szükséges perbeli képviselet hiányához, vagy a bíróság múködését gátló körülményekhez kapcsolódnak. ${ }^{5}$

A peres eljárásra vonatkozó szabályokhoz képest speciális, ha a fél meghal vagy megszűnik. A végrehajtást kérô illetve az adós halálának (megszűnésének) kérdése felmerülhet egyrészt a bíróság előtti eljárás során a végrehajtás elrendelésekor, másrészt a végrehajtó eljárása során a végrehajtás foganatosításakor.

Amennyiben a végrehajtás elrendelésekor a végrehajtást kérő vagy az adós meghalt (megszűnt), a végrehajtás elrendelésére - perbeli jogképesség hiányában - nincs lehetőség, azaz a kérelem elutasitásának van helye, kivéve, ha a végrehajtás elrendelése iránti kérelemmel együtt jogutódlás megállapítása iránti kérelem is előterjesztésre került. Ebben az esetben a bíróság először megállapítja a jogutódlást, majd elrendeli a végrehajtást, így az eljárás félbeszakadásáról nem lehet szó. A gyakorlatban általában együtt nyúitja be a jogosult (végrehajtást kérô) a végrehajtható okirat kiállítása iránti kérelmet a jogutódlás megállapítása iránti kérelemmel. Ilyenkor a jogutódlást megállapító végzés jogerőre emelkedése után lehet dönteni a végrehajtható okirat kiállitása tárgyában.

Amennyiben a végrehajtó tudomást szerez a felek személyében bekövetkezett változásról - a Vht. 39. \(3) bekezdés kivételével - minden esetben hivatalból terjeszti be a végrehajtási ügyet a bírósághoz. ${ }^{6}$ Ekkor a végrehajtási ügy folyamatban marad, azonban nem a végrehajtó, hanem a végrehajtást foganatosító bíróság előtt. $^{7}$

A végrehajtást foganatosító bíróságnak - ha e törvény másként nem rendelkezik - azt a bíróságot kell tekinteni, amely mellé az eljáró önálló bírósági végrehajtót kinevezték, illetve azon törvényszék székhelye szerinti járásbíróságot, amely törvényszékre a törvényszéki végrehajtót kinevezték, fővárosi törvényszéki végrehajtó esetében pedig a Pesti Központi Kerületi Bíróságot. ${ }^{8}$ A bíróság eljárása - a beterjesztett végrehajtási iratok áttanulmányozását követően - attól függően alakul, hogy a változás a végrehajtást kérő, vagy adós személyében következik-e be, feltéve hogy egyik esetben sem kerül csatolásra - természetes személy vonatkozásában - a jogerős hagyatékátadó végzés vagy öröklési bizonyítvány. Előbbi rendhagyónak tekintendő abból a szempontból, hogy hivatalból történő bizonyításnak van helye a jogviszony jellegénél fogva, hiszen az adósnak nem érdeke a végrehajtást kérő jogutódjának felkutatása.

Ekkor a bíróság a közjegyző irányába megkeresést bocsát ki a jogutódlás megállapításához szükséges dokumentumok beszerzése végett, és annak esetleges eredménytelensége vagy elhúzódása a bírósági eljárás félbeszakadását eredményezi. Ilyenkor a végrehajtó köteles a behajtott összeget bírósági letétbe helyezni.

\footnotetext{
3 Azokra az eljárási kérdésekre, amelyeket e törvény eltérően nem szabályoz, a Pp. szabályait a nemperes eljárás sajátosságaiból eredő eltérésekkel és a bírósági polgári nemperes eljárásokban alkalmazandó szabályokról, valamint egyes bírósági nemperes eljárásokról szóló törvénynek a bírósági polgári nemperes eljárásokra vonatkozó általános rendelkezéseit kell alkalmazni.

4 Gyüre Péter: A bírósági végrehajtás elrendelésére vonatkozó általános szabályok figyelemmel a szubszidiárius jelleggel alkalmazandó új polgári perrendtartás rendelkezéseire. Eljárásjogi Szemle, 2018/1. sz., 47-53., 49.

${ }^{5}$ Wopera Zsuzsa: A polgári perrendtartásról szóló 2016. évi CXXX. törvény magyarázata, Budapest, Wolters Kluwer Kft., 2017. 176.

${ }^{6}$ Civilisztikai Kollégiumvezetők 2013. május 8.-10. napján tartott Országos Tanácskozásán elhangzottak.

${ }^{7}$ BH2011. 106.

8 Vht. 225. S (6) bekezdés.
} 
Debreceni Jogi Múhely 2018. (XV.) 1-2.

Debreceni Egyetem, Állam- és Jogtudományi Kar, Debrecen

(University of Debrecen, Faculty of Law, Debrecen)

DOI 10.24169/DJM/2018/1-2/2

Eltérő mechanizmus érvényesül akkor, ha az adós személyében következik be változás, mivel a felek eljárástámogatási és igazmondási kötelezettségéből ${ }^{9}$ adódóan a végrehajtást kérő feladata lesz a jogerős hagyatékátadó végzés (öröklési bizonyítvány) beszerzése, következtetésképpen a bíróság határidő tűzésével hiánypótló végzést bocsát ki a végrehajtást kérô részére. Amennyiben a Pp. 147. \ (1) bekezdésében meghatározott maximális - negyvenöt napos - határidő eredménytelenül telik el, az érdemi intézkedés milyensége a végrehajtást kérô nyilatkozatától vagy annak hiányától függ. Ha a végrehajtást kérô akként nyilatkozik, hogy a jogutódlás megállapításához szükséges dokumentumokat azért nem sikerült becsatolni, mert a hagyatéki eljárás még folyamatban van, esetlegesen az meg sem kezdődött - az ügy további nyilvántartásba helyezése helyett - célszerű az eljárás félbeszakadásának megállapítása a bírósági időszerűségi követelményekre figyelemmel. ${ }^{10}$ Jognyilatkozat hiányában a jogutódlás megállapítása iránti kérelem visszautasítására vagy a végrehajtási iratok végrehajtónak történő visszaküldésére kerül sor attól függően, hogy az iratok beterjesztése kérelemre vagy hivatalból történt-e. A végrehajtást kérőt a visszautasítással azonban nem éri jogvesztés, mert a jogerős hagyatékátadó végzés (öröklési bizonyítvány) rendelkezésére állásakor a jogutódlás megállapítása iránti kérelmet újra előterjesztheti, majd a végrehajtást foganatosító bíróság a jogutódlást megállapíthatja. ${ }^{11}$

Az eljárás félbeszakadásának elsődleges jogkövetkezménye, hogy az eljárás félbeszakadásával minden határidő megszakad. A félbeszakadt ügyeket a befejezéstől számított egy évig nyilvántartásba kell helyezni, majd egy év eltelte után helyezhető irattárba a félbeszakadt ügy ügyirata. ${ }^{12}$ Az eljárás félbeszakadásának további jogkövetkezménye, hogy a félbeszakadás tartama alatt tett minden bírói intézkedés, valamint a felek által teljesített minden eljárási cselekmény hatálytalan. Kivételt képeznek azok a bírói rendelkezések, illetve eljárási cselekmények, amelyek az eljárás félbeszakadásával, illetve továbbfolytatásával kapcsolatosak, ezek ugyanis a félbeszakadás tartama alatt sem tekinthetőek hatálytalannak. ${ }^{13}$

\section{A bírósági végrehajtás felfüggesztése}

A miniszteri indokolás szerint „felfüggesztésre akkor kerül sor, amennyiben a külső körülmények hatása az eljárásra közvetlen, az okok és körülmények kezelése az eljárás szereplőinek magatartásától függ, avagy az eljárás jogi alapjai, ezzel a legitimitása kérdőjeleződik meg. A felfüggesztés olyan eljárási cselekmény, amit valaki, valamely, a törvényben, jogszabályban meghatározott szerv, szervezet elrendel. A felfüggesztéshez döntés szükséges, a felfüggesztés a döntés következtében szakítja meg az eljárást. Akkor is dönteni kell az eljárás felfüggesztéséről, ha egy külső objektív körülmény miatt kell az eljárást megszakítani, mivel a jogi szabályozás a döntésen keresztül teremti meg a külső körülmény eljárási relevanciáját."

Jelen fejezetben a végrehajtás felfüggesztésére vonatkozó rendelkezések - az uniós jogi szabályozás kivételével - kerülnek kifejtésre, mellyel kapcsolatos részletszabályokat a Vht. 48-51. 』-ai tartalmazzák. Ha a végrehajtást valamennyi végrehajtási cselekményre kiterjedő hatállyal felfüggesztették, (ügyvitelileg) befejezett a végrehajtási ügy. ${ }^{14}$

\footnotetext{
9 A polgári perrendtartásról szóló 1952. évi III. törvény (a továbbiakban: 1952-es Pp.) 3. \(3) bekezdése szerinti tárgyalási elv.

10 Handó Tünde, az Országos Bírósági Hivatal elnöke által 2016. április 22. napján meghirdetett Fenntartható Fejlődés program egyik alappillére a magas színvonalú, időszerű ítélkezés.

${ }^{11}$ Dallos Zoltán: A polgári perrendtartásról szóló 1952. évi III. törvény (Pp.) rendelkezéseinek alkalmazása a bírósági végrehajtásról szóló 1994. évi LIII. törvény (Vht.) felhatalmazása alapján, http://www.jogiforum.hu/publikaciok/470 letöltés időpontja: 2012. május 2.

12 Az Országos Bírósági Hivatal Elnökének 17/2014. (XII. 23.) OBH utasítása a bíróságok egységes iratkezelési szabályzatáról 105. \(1) bekezdés.

13 Varga István: A polgári perrendtartás és a kapcsolódó jogszabályok kommentárja I., Budapest, HVG Orac, 2017. 509.

${ }^{14}$ A bírósági végrehajtási ügyvitelrôl és pénzkezelésről szóló 1/2002. (I.17.) IM rendelet (a továbbiakban: Vüsz.) 34. S a) pont.
} 
Debreceni Jogi Múhely 2018. (XV.) 1-2.

Debreceni Egyetem, Állam- és Jogtudományi Kar, Debrecen

(University of Debrecen, Faculty of Law, Debrecen)

DOI 10.24169/DJM/2018/1-2/2

\subsection{A felfügges:tés esetei}

\subsubsection{A végrehajtás felfüggesztése a végrehajtást kérő kérelmére}

A végrehajtást foganatosító bíróság köteles a végrehajtást felfüggeszteni, ha ezt kívánta a végrehajtást kérô, és a felfüggesztés másnak a jogát (például adós, végrehajtó, zálogjogosult) nem sérti. Ez az eset a végrehajtást kérő rendelkezési elvéből vezethető le, és nem biztosít diszkrecionális jogkört a jogalkalmazó részére, vagyis a törvényi feltételek fennállása esetén kötelező annak elrendelése, és - erre irányuló kifejezett végrehajtást kérői kérelemre - a végrehajtás folytatása is. Megjegyzendő, hogy a jogalkotó ennél az egy formációnál lehetôvé teszi, hogy bíró vagy bírósági titkár helyett végrehajtási ügyintéző járjon el. 15

\subsubsection{A végrehajtás felfüggesztése a zálogjogosult bekapcsolódási kérelmére tekintettel}

Ha a zálogjogosult ingó vagy ingatlan vagyontárgy vonatkozásában zálogjogi bekapcsolódás iránti kérelmet terjesztett elő, a kérelem beérkezését követő 3 munkanapon belül a bíróság a végrehajtást felfüggeszti.

Ha a jogi képviselôvel eljáró zálogjogosult hiányos kérelmet nyújt be, azt érdemi vizsgálat nélkül el kell utasítani, azonban „kvázi végrehajtási kérelemről” lévén szó nem a Vht. 12. \ (2) bekezdésére hivatkozással, hanem a Vht. 9. \-a alapján alkalmazandó Pp. 176. \(1) bekezdés j) pontja alapján. Eltérő bírósági gyakorlat alakult ki abban a tekintetben, hogy a jogi képviseló nélkül eljáró hiányos zálogjogosulti kérelem előterjesztése esetén mikor kezdődik a 3 munkanapos törvényi határidő. Az egyik álláspont szerint a Vht. 9. \$-a alapján alkalmazandó régi Pp. 95. §-ának (5) bekezdése szerint a keresetlevél csak akkor válthat ki joghatályt, ha az a Pp. 121. és 123. S-aiban foglaltaknak megfelel. ${ }^{16}$ Ennek megfelelően a határidő a hiánytalan kérelem bírósághoz történő érkezésével kezdődik meg, és a hiányos kérelem előterjesztése önmagában nem alapozza meg a végrehajtás felfüggesztését.

A másik álláspont szerint a törvény egyértelmúen meghatározza, hogy a végrehajtás felfüggesztését a kérelem bíróságra érkezésétől számított 3 munkanapon belül el kell rendelni, és a határidő nem tehető függővé attól, hogy a kérelem hiányosan érkezik. A hiányok pótlása - akár kisebb hiányosság esetén is hosszabb időt is igénybe vehet, a felfüggesztés elmaradása ezért a zálogjogosultat hátrányosan érintheti. ${ }^{17}$ Az egyértelmű törvényi rendelkezés és a zálogjogosult érdekekeinek szem előtt tartása jobban védhetôvé teszi utóbbi álláspontot, továbbá nem okoz jogsérelmet egyik félnek sem, legfeljebb fokozott odafigyelést igényel az egyébként is nagymértékben leterhelt bíróságokra nézve azzal, hogy rövid határidôn belül kell megtenni a szükséges intézkedéseket.

A zálogjogi bekapcsolódást engedélyező végzés jogerőre emelkedését követően a végrehajtást foganatosító bíróság a végrehajtásnak a Vht. 48. \(2) bekezdése alapján történt felfüggesztését megszünteti, és erről a végrehajtót értesíti. Meg kell szüntetni a végrehajtás felfüggesztését akkor is, ha a jogosult nem igazolta, hogy az (5) bekezdés szerinti végzés kézhezvételétól számított 8 munkanapon belül a pert megindította. ${ }^{18}$ Ebből következik, hogy a bíróság mind az engedélyező, mind az elutasító végzés jogerőre emelkedését követően köteles rendelkezni a végrehajtás felfüggesztésének megszüntetésérôl. Speciális szabály alkalmazandó, ha az elutasítás oka az, hogy az adós vagy a végrehajtást kérő a nem közokiratba foglalt követelést vitatta, és állitását valószínűsítette, ugyanis amennyiben az elutasító végzés kézhezvételétől számított 8 napon belül a zálogjogosult nem indítja meg a végrehajtási eljárásba történő bekapcsolódás engedélyezése iránti pert, a felfüggesztés megszüntetésének van helye. Ellenkező esetben a bíróság a per jogerős befejezését követően szünteti meg a végrehajtás felfüggesztését, és erről értesíti a végrehajtót. ${ }^{19} \mathrm{~A}$ bíróság külön végzésben rendelkezik a végrehajtás felfüggesztésének megszüntetésérôl, azonban megosztott a gyakorlat abban, hogy a végzéssel szemben van-e helye fellebbezésnek. A tanulmány szerzőjének álláspontja szerint mivel ez nem a bíróság diszkrecionális jogkörén - hanem törvényi

\footnotetext{
15 Vht. 261. \b) pont.

${ }_{16}$ Balogh Olga: Az ingóvégrehajtás, In: Sáriné dr. Simkó Ágnes (szerk.): A megújult bírósági végrehajtás, Budapest, HVG Orac, 2006. 319.

17 Kovács-Hegedűs Vera: A zálogjogosult bekapcsolódása a végrehajtási eljárásba, Pro Futuro 2015/2. szám, 150.

18 Vht. 114/A. $\int(7)$ bekezdés.

${ }^{19}$ Kiss Nikolett - Osztovits András - Pomeisl András - Villám Krisztián: A bírósági végrehajtásról szóló 1994.évi LIII. törvény nagykommentárja, Budapest, Opten Kft., 2015. 292.
} 
Debreceni Jogi Múhely 2018. (XV.) 1-2.

Debreceni Egyetem, Állam- és Jogtudományi Kar, Debrecen

(University of Debrecen, Faculty of Law, Debrecen)

DOI 10.24169/DJM/2018/1-2/2

rendelkezésen - alapuló járulékos jellegú intézkedés, nincs helye fellebbezésnek.

\subsubsection{A végrehajtás felfüggesztése az adós kérelmére}

$\mathrm{Az}$ adós kérelmére csak kivételesen, meghatározott feltételek fennállása esetén függeszthetô fel a végrehajtás, azonban - eltérően az eddig ismertetett módozatoktól - ez csupán lehetőség. Egyrészt fontos, hogy az adós a felfüggesztésre okot adó kivételes méltányolható körülményeket igazolja. E körben a kivételesség azt jelenti, hogy a körülménynek nagy súlya van, azaz kiemelt jelentőségú, másrészt csak átmeneti jelleggel áll fenn. Erre jó példa az adós munkahelyének önhibáján kívül történő, időleges elvesztése, valamint tartásra jogosult hozzátartozójának maradandó fogyatékosságot, illetőleg egészségkárosodást nem eredményező balesete. A Vht. 48. \(5) bekezdésében meghatározott körülmények nem kimerítően, csupán példálózó jelleggel kerültek meghatározásra a jogalkotó által, következésképpen más okokra is lehet hivatkoznia az adósnak.

További kívánalom, hogy az adóst az eljárás során nem sújtották rendbírsággal, melynek nyilvánvaló oka, hogy csak az várhat méltányosságot a bíróságtól, aki a végrehajtás során jogszerú magatartást tanúsított. Célszerú a kérelem elbírálását megelőzően a végrehajtást kérő nyilatkozatának beszerzése, de szükség esetén a bíróság a feleket akár meg is hallgathatja. Hangsúlyozandó, hogy kizárólag az adós kérheti, mert amennyiben esetlegesen egyéb érdekelt (például adós házastársa) kéri a végrehajtás felfüggesztését, perbeli legitimáció hiányára tekintettel a kérelem elutasításnak van helye a Vht. 9. \-a alapján alkalmazandó Pp. 176. \(1) bekezdés g) pontja alapján.

\subsubsection{A végrehajtás felfüggesztése ingatlan kiürítésekor}

Ha a végrehajtás ingatlan kiürítése iránt folyik, felfüggesztés az adós kérelmére egy ízben, legfeljebb 6 hónapra rendelhetô el..$^{20}$ A jogalkotó a felfüggesztés ezen lehetőségét két szempontból is szúkíti, hiszen egyrészt csak egyszeri alkalommal van rá lehetőség, másrészt meghatározott időtartamra, ami legfeljebb 6 hónap. A Vht. 48. \(7) bekezdése arra is kitér, hogy ha önkényesen elfoglalt lakás kiürítéséről van szó, vagy ha a kötelezett a teljesítési határidő vonatkozásában a Pp. 344. \ (6) bekezdése szerinti kedvezményben részesült, nincs helye a végrehajtás felfüggesztésének. Ha egyéb esetben a végrehajtást kérô határozott időre kéri a végrehajtás felfüggesztését, azt tartalma szerint a teljesítésre adott halasztásnak kell tekinteni, ami a végrehajtás szünetelését eredményezi a Vht. 52. \f) pontja alapján. ${ }^{21}$

3.1.5. A végrehajtás felfüggesztése a végrehajtható okirat vagy a végrehajtó intézkedésével szembeni jogorvoslatra tekintettel

A végrehajtható okirattal szembeni jogorvoslatok a végrehajtási lap visszavonása/végrehajtási záradék törlése, a fellebbezés, felülvizsgálat és egyéb jogorvoslatok, míg a végrehajtó intézkedésével szembeni jogorvoslat a végrehajtási kifogás. Időnként előfordulnak olyan esetek, amikor alaposan vélelmezhető, hogy a jogorvoslat előterjesztője számára kedvező döntés fog születni az ügyben. Így célszerű felfüggeszteni a végrehajtást például akkor, amikor végrehajtási lap visszavonása iránti kérelmet terjeszt elő az adós (mint mögöttes felelős) arra hivatkozással, hogy a végrehajtást kérő a felszámolási eljárásban a nem természetes személy adóssal (mint elsődleges kötelezettel) szemben a jogvesztő határidőn belül nem jelentette be a hitelezői igényét, továbbá akkor is, ha az adós az ingatlanárveréssel szemben végrehajtási kifogást terjeszt elő a törvényes határidôn belül. Hangsúlyozandó, hogy a felfüggesztés ezen verziója csupán lehetôség, melynek alkalmazása mindig az adott konkrét ügy függvénye.

\subsubsection{A végrehajtás felfüggesztésének külön törvényben meghatározott esetei}

A bíróság a végrehajtást azokban az esetekben is felfüggesztheti, amelyekben ezt a Pp. vagy más törvény lehetôvé teszi. A Pp. által felfüggeszthető esetek négy csoportba sorolhatóak. Az elsô csoportba tartoznak azok, amikor valamiképpen a végrehajtandó határozat hatálya illetve jogereje vitás (például kézbesítési vélelem). A második csoportot az előzetes végrehajthatósággal kapcsolatos esetek képezik. A másodfokú tanács elnöke határoz a végrehajtás felfüggesztésének kérdésében, ha az elsőfokú bíróság a határozatot a törvény ellenére nyilvánította előzetesen végrehajthatónak. ${ }^{22}$ A harmadik csoportba a jogerős és

\footnotetext{
${ }^{20}$ Vht. 48. \(6) bekezdés.

${ }^{21}$ Pestovics Ilona: Bírósági végrehajtás, Budapest, Novissima, 2010, 95.

22 Pp. 367. \ (2) bekezdés.
} 
Debreceni Jogi Múhely 2018. (XV.) 1-2.

Debreceni Egyetem, Állam- és Jogtudományi Kar, Debrecen

(University of Debrecen, Faculty of Law, Debrecen)

DOI 10.24169/DJM/2018/1-2/2

végrehajtható határozatokkal szembeni jogorvoslatokkal kapcsolatos esetek tartoznak, melyek tipikusan a felülvizsgálat és perújítás, azonban utóbbi előterjesztése önmagában nem halasztó hatályú a végrehajtásra. A végrehajtás felfüggesztésének feltétele, hogy a perújítás sikere valószínűnek mutatkozzék. A siker valószínűsége azt jelenti, hogy a rendelkezésre álló adatok valószínűsítik, hogy a perújítási kérelem nem lesz eredménytelen. ${ }^{23}$ A negyedik csoportba pedig a végrehajtás elrendelése és foganatosítása kapcsán indított olyan peres eljárások tartoznak, mint a végrehajtás megszüntetése és korlátozása iránti per, végrehajtási igényper és a végrehajtási eljárásba történő bekapcsolódás engedélyezése iránti per.

A Pp.-n túl más törvény is lehetővé teheti a végrehajtás felfüggesztését, így például a választottbírósági ítélet érvénytelenítése iránti perben az eljáró bíróság a választottbírósági ítélet végrehajtását a választottbíráskodásról szóló 1994. évi LXXI. törvény 56. \(1) bekezdés alapján felfüggesztheti.

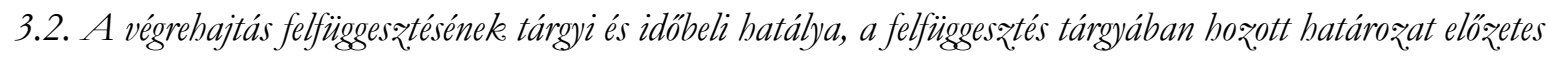 végrehajthatósága}

Tárgyi hatályát tekintve a felfüggesztés nem terjedhet túl a feltétlenül szükséges mértéken, melynek hátterében az ésszerű időn belüli befejezés elve áll. A szükséges mérték megállapításánál figyelemmel kell lenni a felfüggesztés okára és céljára, valamint a felek méltányos érdekeire. ${ }^{24}$ Indokolt az egész végrehajtás felfüggesztése, ha valamelyik fél a végrehajtható okirat vagy végrehajtandó határozat egészét támadó jogorvoslati kérelmet nyújt be. Pontosan determinált azonban a tárgyi hatály a zálogjogi bekapcsolódás és az adós kérelmére történő felfüggesztés esetén. A felfüggesztés nem terjed ki a végrehajtás foganatosítása során szükséges bírósági döntések (például jogutódlás) meghozatalára és a felfüggesztést megelőzően elöterjesztett végrehajtási jogorvoslati kérelmek elbírálására.

A végrehajtást foganatosító bíróságnak a kérelemrôl 15 napon belül - zálogjogi bekapcsolódásnál 3 munkanapon belül - kell dönteni, mely határidő kezdő időpontja - a zálogjogi bekapcsolódás kivételével az elbíráláshoz szükséges iratok maradéktalan rendelkezésre állása.

A felfüggesztés - időbeli hatályát tekintve - nyomban beáll, amint az illetékes bíróság a felfüggesztő határozatot meghozza, tekintet nélkül arra, hogy a végzés jogerős-e vagy sem, hiszen a felfüggesztést elrendelő végzés elleni jogorvoslat a végrehajtásra nézve nem halasztó hatályú. A felfüggesztés meghozatala és közlése között eltelt időben megtett cselekmények hatálytalanok, amelyre tekintettel írja elő a Vht. 50. \ (2) bekezdése, hogy a végzést azonnal közölni kell a végrehajtóval. ${ }^{25}$ A közlés elmaradása nem teszi hatályossá az időközben foganatosított végrehajtási cselekményeket, és a végrehajtó nem hivatkozhat arra sem, hogy a vele rövid úton (telefonon vagy távmásolat útján) közölt felfüggesztő határozat hatálya vele szemben nem állt be azért, mert részére nem kézbesítették szabályszerűen, illetve a neki megküldött határozat nem minősül közokiratnak. ${ }^{26}$

\subsection{A végrehajtás felfüggesztésének felülvi «sgálata, a felfüggesztett végrehajtás folytatása}

A felfüggesztés fenntartásának indokoltságát a felfüggesztést elrendelő bíróság bármelyik fél - ideértve az érdekeltet, végrehajtót is - indokolt kérelmére felülvizsgálja. A bíróság a felfüggesztés felülvizsgálatára irányuló kérelmet csak akkor köteles érdemben vizsgálni, ha abban a fél megjelöli azt a körülményváltozást, amelyre tekintettel a végrehajtás felfüggesztésének felülvizsgálatát indokoltnak tartja. Az adós kérelmére történő felfüggesztésnél célszerűnek látszik a jogszabályi rendelkezés akként történő megváltoztatása, hogy meghatározott idő elteltével (például 3 hónap) a bíróságnak kötelező megvizsgálnia a felfüggesztés fenntartásának indokoltságát - főleg olyan esetekben, amikor a végrehajtást kérő valamilyen oknál fogva akadályoztatva van jogai gyakorlásában.

A Vht. 51. \-a szerint a felfüggesztett végrehajtást a felfüggesztést elrendelő bíróság - illetőleg a polgári perrendtartásban vagy más törvényben megállapított más bíróság - intézkedésére lehet tovább folytatni.

\footnotetext{
23 BDT2000. 258.

${ }^{24}$ Kiss Nikolett - Osztovits András - Pomeisl András - Villám Krisztián: im. 303.

${ }^{25}$ Lehetőség szerint telefonon vagy telefax útján.

${ }^{26}$ Kiss Nikolett - Osztovits András - Pomeisl András - Villám Krisztián: im. 304.
} 
Debreceni Jogi Múhely 2018. (XV.) 1-2.

Debreceni Egyetem, Állam- és Jogtudományi Kar, Debrecen

(University of Debrecen, Faculty of Law, Debrecen)

DOI 10.24169/DJM/2018/1-2/2

Ha a felfüggesztésre okot adó körülmény megszűnik, a bíróság kifejezett intézkedése szükséges a végrehajtás folytatásához, azonban ez nem feltétlenül a végrehajtást elrendelô bíróságot fogja jelenteni, ugyanis például felülvizsgálati eljárásnál a végrehajtást a Kúria függeszti fel, viszont a felfüggesztés megszüntetése tárgyában már az elsőfokú bíróság intézkedik az iratok visszaküldését követően.

\section{A bírósági végrehajtás szünetelése}

A miniszteri indokolás szerint „a jogszabályi speciális felhatalmazásoktól, törvényi kivételektől és tilalmaktól függetlenül a szünetelés mindenütt az eljárás folytathatatlanságát, a további eljárási cselekmények lehetetlenségét jelenti.” A bírósági végrehajtás során a Pp. 121. \-ában foglalt szünetelési okok nem alkalmazhatók, mivel a Vht. 52. \$-a a szünetelési okokat konkrétan és tételesen meghatározza. Ezen okok az adós körülményiben felmerülő objektív okokra, a végrehajtást kérő szubjektív magatartására és a külön törvényben meghatározott rendelkezésekre vezethetőek vissza. ${ }^{27}$ A Vht. 54. \(1) és (2) bekezdése pedig a szünetelő végrehajtás folytatásának okait nevesíti.

A szünetelés jogkövetkezményei lényegében azonosak a felfüggesztés következményeivel. Az addig elvégzett eljárási cselekmények megtartják a hatályukat, további eljárási cselekményre azonban még kivételesen sem kerülhet sor, eltérően a végrehajtás felfüggesztésétől, amelynek esetén az eljárás a felfüggesztéssel nem érintett vagyontárgy vonatkozásában folytatódhat. ${ }^{28}$ Így végrehajtási eljárás szünetelése alatt nincs helye például a becsérték újbóli megállapításának, hiszen az végrehajtási cselekmény. ${ }^{29}$ A szünetelés tartama alatt végrehajtási cselekmény nem végezhetô, a szünetelésnek nincs időbeli korlátja, az eljárás folytatásának azonban a végrehajtási jog elévülése határt szab. ${ }^{30}$

További eltérés a végrehajtás felfüggesztéséhez képest, hogy a felfüggesztést a bíróság rendeli el, a szünetelést pedig a végrehajtó állapítja meg. Amennyiben a szünetelés oka megszűnt, a végrehajtást folytatni kell. A végrehajtó a végrehajtás szüneteléséről - az okát is feltüntető - jegyzőkönyvet készít, és a jegyzőkönyv másolatát megküldi a feleknek. Ennek elmaradása a végrehajtó kártérítési felelősségét is megalapozhatja, ugyanis a felek ebből a jegyzőkönyvből szerezhetnek tudomást a végrehajtási eljárás szüneteléséről. ${ }^{31}$ A Vüsz. 34. $\$ b) pontja értelmében befejezett a végrehajtási ügy akkor is (ügyviteli befejezés), ha a végrehajtási ügy szünetel. Mivel bizonytalan, hogy a szünetelő végrehajtás mikor fog folytatódni, ügyviteli szempontból nem célszerủ a szünetelő végrehajtási ügyet továbbra is - mint folyamatban lévő́t - nyilvántartani. Az ügyet a végrehajtási statisztikában befejezettként kell lejelenteni. ${ }^{32}$ $\mathrm{Az}$ ügyviteli befejezésre tekintettel a végrehajtó elkészítheti a bírósági végrehajtói díjszabásról szóló 35/2015. (XI. 10.) IM rendelet (a továbbiakban Dsz.) 28. \-a szerinti dijjegyzéket, tehát érvényesítheti a végrehajtási költségekkel kapcsolatos igényét.

Az alábbiakban a Vht. 52. \-ában ${ }^{33}$ taxatíve meghatározott szünetelési okok kerülnek ismertetésre.

\footnotetext{
${ }^{27}$ Király Lilla: A bírósági végrehajtás Magyarországon és az Európai Unióban, PTE-ÁJK Végrehajtási jogi szakjogász jegyzet, 2015. 33.

${ }^{28}$ Vida István: A végrehajtás foganatosításának közös szabályai, In Németh János - Kiss Daisy (szerk.): A bírósági végrehajtás magyarázata, Budapest, KJK-KERSZÖV, 2004, 374.

${ }^{29}$ BH1997. 33.

${ }^{30}$ Fôvárosi Ítélótábla 9.Pf.20.179/2012/5.

${ }^{31}$ Gyovai Márk: A végrehajtási eljárás szünetelése, In: Wopera Zsuzsa - Gyovai Márk (szerk.): Kézikönyv a bírósági végrehajtás foganatosításához, Budapest, Wolters Kluwer Kft., 2016. 85.

32 B. Korek Ilona: A végrehajtás foganatosításának közös szabályai, In: Sáriné dr. Simkó Ágnes (szerk.): A bírósági végrehajtás, Budapest, HVG Orac, 2009. 189.

33 A végrehajtás szünetel, ha

a) az adós személyazonossága a szükséges adatok hiányában nem állapítható meg,

b) az adós meghalt, vagy a nem természetes személy adós megszűnt, és a végrehajtást kérő nem kérte a jogutódlás megállapítását,

c) a végrehajtást kérő az eljárásban való közreműködését megtagadta,

d) az adósnak nincs lefoglalható vagyontárgya, illetőleg a lefoglalt vagyontárgy értékesítése sikertelen volt,

e) a végrehajtást kérô a végrehajtási költséget - bár köteles rá - nem előlegezte,

f)az adós a teljesítésre halasztást kapott, vagy a részletekben való teljesítést engedélyezték, illetve állapította meg
} 
Debreceni Jogi Múhely 2018. (XV.) 1-2.

Debreceni Egyetem, Állam- és Jogtudományi Kar, Debrecen

(University of Debrecen, Faculty of Law, Debrecen)

DOI 10.24169/DJM/2018/1-2/2

\subsection{Az adós személyazonosságának megállapithatatlansága a szüleséges adatok biánya miatt}

A végrehajtást kérő 2016. január 1. napjától a természetes személy adós azonosításához szükséges adatok közül közölni köteles legalább a születés helyét, idejét és anyja nevét, tehát mindhárom adatot együttesen. Amennyiben a végrehajtható okirat az adós valamely adatát tévesen tartalmazza, a kijavítás iránti kérelem végrehajtást elrendelő bíróság általi elbírálásáig a végrehajtás szünetel.

\subsection{Az adós halála (megszünése) esetén a végrehajtást kérö nem kéri a jogutódlás megállapitását}

Ha az adós meghalt vagy a nem természetes személy adós megszűnt, a végrehajtási eljárás a jogutóddal szemben folytatható. A jogutódlással kapcsolatos rendelkezéseket a Vht. 39. \$-a tartalmazza. Amennyiben a végrehajtást kérő a végrehajtó vagy bíróság felhívására akként nyilatkozik, hogy nem kéri a jogutódlás megállapítását, illetôleg a felhívásra a megadott határidőn belül nem nyilatkozik, a végrehajtás szünetel egészen addig, amíg a végrehajtást kérô a jogutódlás megállapítása iránti kérelmét elő nem terjeszti.

\subsection{A végrehajtást kéró az eljárásban való közrremüködését megtagadja}

A Vht. 40. \(1) bekezdése szerint a végrehajtást kérő köteles a végrehajtandó követelés megszűnését és csökkenését haladéktalanul bejelenteni a végrehajtónak, köteles egyúttal a végrehajtó felhívásának megfelelően a $34 . \$(5)$ bekezdésében említett összegeket is megfizetni. Amennyiben a végrehajtást kérő nem tesz eleget fenti kötelezettségének, a végrehajtás szünetel. Megjegyzendő, hogy ha a végrehajtást kérő, mint az ügy ura, az eljárásban való közremúködését megtagadja, jogkövetkezményként vele szemben a Vht. 45/A. \-a szerinti rendbírság kiszabására nincs lehetôség.

\subsection{Az adósnak nincs lefoglalható vagyontárgya, illetöleg annak értékesitése sikertelen}

A Dsz. 22. §-a szerint, ha a Vht. 52. \ d) pontja alapján szünetelő végrehajtási eljárás során a végrehajtót megillető munkadíj összege nem térült meg, a munkadíj fennmaradt részét a végrehajtást kérőnek az eljárás befejezésekor készített díjjegyzék alapján kell megfizetnie a végrehajtó részére. Az adós lefoglalható vagyontárgya hiányában szünetelő végrehajtási eljárásban a végrehajtási jog elévülése bekövetkezhet a szünetelés tartama alatt. ${ }^{34}$

A végrehajtást akkor lehet folytatni, ha valószínűsítették, hogy az adósnak van olyan vagyontárgya, amely lefoglalható, illetőleg értékesíthető. A „valószínúsítették” szó (többes szám) nyelvtani értelmezéséből kiindulva tehát az eljárás folytatását - a gyakorlatban rögzült állásponttal ellentétben - nem csak a végrehajtást kérő kérelmére lehet megtenni. A végrehajtást kérőn kivül a végrehajtó az eljárás azon szereplóje, aki valószínűsítheti, hogy az adósnak van olyan vagyontárgya, amely lefoglalható. ${ }^{35}$

\subsection{A végrehajtást kérö indokolt költségelöleg megfizetési kötelęettségének nem tesz eleget}

A végrehajtó - főszabály szerint - az ügy iratainak megérkezése után 8 napon belül, soron kívüli ügyben 3 napon belül felhívja a végrehajtást kérőt az eljárás kezdetén megfizetendő költség megfizetésére olyan határidővel, hogy az eljárási cselekményeket előreláthatólag határidőn belül tudja elvégezni. ${ }^{36}$

A szünetelés ezen verziójánál - ide nem értve azokat az eseteket, amelyekben költségmentesség folytán az állam köteles a végrehajtási költség előlegezésére - nincs helye az eljárás folytatásának, ha a szünetelés megállapításától számított 1 éven belül a költséget nem előlegezték; ebben az esetben a végrehajtás - ipso jure - megszűnik. Időnként előfordul, hogy az ily módon megszűnt végrehajtási eljárásban terjesztenek elő

\footnotetext{
számára a végrehajtó,

g) külön törvény így rendelkezik.

${ }^{34} \mathrm{EBH} 2004.1037$.

35 Gyovai Márk: im. 92-93.

36 Kivéve a Vht. 4. \-a, 225. \(3) bekezdése és az Art. 158. \(3) bekezdése alapján átvett ügyeket, továbbá a gyermektartásdíj behajtására irányuló eljárást.
} 
Debreceni Jogi Múhely 2018. (XV.) 1-2.

Debreceni Egyetem, Állam- és Jogtudományi Kar, Debrecen

(University of Debrecen, Faculty of Law, Debrecen)

DOI 10.24169/DJM/2018/1-2/2

jogutódlás megállapítása iránti kérelmet. Ez esetben a kérelmet el kell utasítani arra hivatkozással, hogy nincs olyan végrehajtási eljárás folyamatban, amelyben a jogutódlást meg lehetne állapítani. Amennyiben az egyszer kiállított végrehajtási lappal elrendelt végrehajtás a költségelőlegezés elmulasztása folytán szünetelés követően megszűnt, a végrehajtást kérô új végrehajtási eljárást kezdeményezhet. A végrehajtás ily módon történt megszűnése nem jelenti a követelés megszűnését, ezért a végrehajtási lapot ismételt kérelemre - egyéb akadály hiányában - ki kell állítani. ${ }^{37}$

\subsection{Az adós a teljesitésre halasżtást kapott, vagy a részletekben való teljesitést engedélyezték, illetve állapitotta meg sqámára a végrehajtó}

Ilyenkor a szünetelés megállapításáról nem kell felvennie jegyzőkönyvet a végrehajtónak, ennek tényét azonban fel kell jegyeznie. Az adós kötelezettségének teljesítésére halasztást - a lakóingatlan kiürítésének elhalasztása kivételével - kizárólag a végrehajtást kérő, míg részletfizetési lehetőséget a végrehajtást kérőn túl a végrehajtó biztosíthat. Szükséges megjegyezni, hogy 2018. január 1-jétől a Pp. megszünteti a korábbi jog alapján fennálló párhuzamos döntési jogkört, ugyanis a bíróság csak addig dönthet az utólagos részletfizetés engedélyezése iránti kérelemről, ameddig a kötelezettség teljesítése iránt nem indult meg a bírósági végrehajtás, utóbbi folyamatban léte alatt a végrehajtó határozhat a részletfizetés engedélyezése tárgyában. ${ }^{38}$ Ezáltal a régi Pp. 217. \ (3) bekezdéséhez kapcsolódó Pk. 188. számú állásfoglalásban foglaltak meghaladottá váltak, amint azt a Kúria is kimondta az 1/2017 PJE határozatában.

A végrehajtást kérő a rendelkezési jogából eredően bármikor engedélyezhet az adós részére részletfizetési lehetőséget vagy halasztást, amelynek nincsen jogszabályi korlátja, azonban ennek tényérôl értesíteni kell a végrehajtót.

A végrehajtó a Vht. 52/A. \-ban meghatározottak szerint - egy úgynevezett kétlépcsős eljárásban biztosíthat részletfizetést kizárólag természetes személy adós részére, amennyiben nem adótartozás vagy adók módjára behajtandó köztartozás a végrehajtás tárgya. A jogalkotó lehetővé teszi a végrehajtó által megállapított részletfizetés feltételeinek megváltoztatását, ha azzal a végrehajtást kérő nem ért egyet.

\subsection{Külön törvény így rendelkęile}

A hatályos szabályozásban három (külön) törvény rendelkezik a végrehajtási eljárás szüneteléséről. A csődeljárásról és felszámolási eljárásról szóló 1991. évi XLIX. törvény 11. \ (2) bekezdésének c) pontja alapján az adóssal szemben a pénzkövetelések végrehajtása - az (1) bekezdésben foglalt követelések kivételével - szünetel, és végrehajtásuk elrendelésének nincs helye. A végrehajtások nem valamennyi fajtája szünetel tehát, csak a pénzkövetelések végrehajtására irányulók (így a meghatározott cselekmény végrehajtására irányuló eljárások folytatódnak.) ${ }^{39}$

A fenti jogszabályon túl a hitelszerződésből eredő kötelezettségeiknek eleget tenni nem tudó természetes személyek lakhatásának biztosításáról szóló 2011. évi CLXX. törvény 15. \(1) bekezdése és az adósságrendezésről szóló 2015. évi CV. törvény 28. 』 (1) bekezdése rendelkezik a végrehajtás szüneteléséről.

A végrehajtást akkor lehet folytatni, ha a szünetelés törvényben megállapított oka megszűnt.

\section{5. Összegzés}

Jelen tanulmány a bírósági végrehajtási eljárás cselekményeinek láncolatát átmeneti jelleggel megakasztó jogintézményeket, nevezetesen a félbeszakadást, a végrehajtás felfüggesztését és a végrehajtás szünetelését prezentálja. A publikációban - gyakorló jogászról lévén szó - hangsúlyos szerepet kap a pragmatizmus, illetve „rávilágít” a jogintézmények alkalmazása során felmerülő problémákra, alternatívákat és de lege

\footnotetext{
37 BDT2012. 2628.

38 Wopera Zsuzsa: im. 449.

${ }^{39}$ Csőke Andrea - Fodorné dr. Lettner Erzsébet - Juhász Csaba: A csődtörvény magyarázata, Budapest, Complex, 2009. 202., Idézi: Gyovai Márk: im. 85.
} 
Debreceni Jogi Műhely 2018. (XV.) 1-2.

Debreceni Egyetem, Állam- és Jogtudományi Kar, Debrecen

(University of Debrecen, Faculty of Law, Debrecen)

DOI 10.24169/DJM/2018/1-2/2

ferenda javaslatot kínálva azok megoldására. A szerző az egyértelmú elhatárolhatóság végett igyekszik felhívni az olvasó figyelmét a jogintézmények közötti összefüggésekre és különbségekre egyaránt. A tanulmány sajátossága továbbá, hogy a Vht. háttérnormájaként alkalmazandó polgári perjogi szabályokat már a 2018. január 1. napján hatályba lépett új polgári perrendtartási kódexből meríti, több helyen is utalva egyidejúleg a régi Pp. szabályozására. 